\title{
IMPLEMENTASI PENDIDIKAN NILAI DALAM PENDIDIKAN AGAMA ISLAM
}

\author{
Ade Imelda Frimayanti \\ adeimelda270377@yahoo.co.id \\ Universitas Lampung
}

\begin{abstract}
Values education is at the core of Islamic religious education, because the purpose of value education is to educate human behavior in the teachings of Islam better known by educating noble morals based on Al-Quran and Hadith. Through value education, the objectives, materials, methods, evaluation activities, and educators in Islamic religious education should support the achievement of the value of education goals. Implementation of values education in Islamic religious education can help learners become human beings who understand the values of their religious teachings and apply these values in their daily lives, so that any negative effects of changing times can be anticipated learners better.
\end{abstract}

Keywords: Values Education and Islamic Religious Education

\begin{abstract}
Abstrak
Pendidikan nilai merupakan inti dalam pendidikan agama Islam, karena tujuan dari pendidikan adalah mendidik perilaku manusia yang didalam ajaran Islam dikenal dengan mendidik akhlak mulia yang berdasarkan Al-Quran dan Hadis. Melalui pendidikan nilai, maka tujuan, materi, metode, kegiatan evaluasi, maupun pendidik dalam pendidikan agama Islam harus mendukung agar suatu tujuan pendidikan nilai tersebut tercapai. Implementasi nilai pendidikan dalam pendidikan agama Islam dapat membantu peserta didik lebih jelas dalam memahami nilai-nilai pendidikan agama Islam dan menerapkan nilai-nilai tersebut dalam kehidupannya sehari-hari, sehingga segala pengaruh negatif dari perubahan zaman dapat diantisipasi peserta didik dengan lebih baik.
\end{abstract}

Kata Kunci: Pendidikan Nilai dan Pendidikan Agama Islam 


\section{PENDAHULUAN}

Islam memandang pendidikan nilai sebagai inti dari pendidikan itu sendiri. Nilai yang dimaksud tersebut adalah akhlak, yakni nilai-nilai yang berasal dari ajaran Agama Islam yang bersumberkan Al-Quran dan Hadis. Nabi Muhammad SAW bersabda: “Orang mukmin yang paling sempurna imannya adalah yang paling baik akhlaknya." (Riwayat Abu Dawud No. 4682 di Kitaabus Sunnah dan Tirmidzi No. 1162 di Kitaabur Radhaa') Demikian Juga dalam sabda Rasullullah yang lain "Tidaklah Aku diutus melainkan untuk menyempurnakan akhlak manusia." Tujuan pendidikan nilai yang merupakan tujuan pendidikan akhlak yaitu dalam rangka melaksanakan perintah Allah, bukan hanya untuk mendapatkan harta, kekuasaan, kenikmatan, ataupun kebahagiaan hidup di dunia semata.

Oleh karena itu dapat kita pahami bahwa pendidikan nilai dalam Ajaran Agama Islam berperanan penting dalam upaya mewujudkan manusia yang utuh atau insan kamil. Tantangan pendidikan Islam khususnya di negara Indonesia adalah bagaimana mengimplementasikan nilai-nilai agama Islam kepada peserta didik secara utuh dan kaffah yang tidak saja menguasai pengetahuan, akan tetapi mempunyai kualitas iman, dan akhlak mulia. Karena tujuan dari pendidikan Islam adalah membentuk manusia yang mempunyai kepribadian yang serasi dan seimbang; tidak saja bidang agama dan keilmuan, melainkan juga keterampilan dan akhlak. Al-Abrasyi menjelaskan bahwa aspek pendidikan akhlak sebagai tujuan pendidikan Agama Islam dan merupakan kunci utama bagi keberhasilan manusia dalam menjalankan tugas kehidupan.

Lebih kongkrit Azyumardi Azra menjelaskan, pendidikan yang baik itu, akan dilihat dari adanya tujuan pembelajaran yang jelas sebagai unsur penting dalam proses kegiatan pembelajaran, menciptakan pribadi-pribadi hamba-hamba Allah SWT yang bertakwa kepada-Nya serta dapat mencapai kehidupan yang bahagia di dunia dan akhirat. Kemajuan ilmu pengetahuan dan teknologi, tidak sedikit dampaknya terhadap sikap dan perilaku manusia, baik sebagai manusia yang beragama maupun sebagai makhluk individu dan mahluk sosial. (Mahyuddin, 1999)

Di sekolah terdapat konflik interpersonal yang meningkat drastis, serta hilangnya kedisiplinan peserta didik di sekolah. Krisis akhlak ini terjadi karena disebabkan sebagian besar orang tidak mau lagi mengindahkan tuntunan agama. Masalah dalam agama tidak mungkin dapat dipisahkan dari kehidupan masyarakat, 
karena agama berfungsi sebagai pedoman hidup yang dijadikan sebagai sumber untuk mengatur norma-norma dalam kehidupan. (Jalaluddin, 1997). Untuk itu pendidikan nilai sangat penting untuk diimplementasikan agar dapat membantu peserta didik menjadi manusia yang bisa memahami nilai-nilai ajaran agamanya tersebut dan menerapkan nilai-nilai tersebut dalam kehidupannya sehari-hari, sehingga segala pengaruh negatif dari perubahan zaman dapat diantisipasi peserta didik dengan lebih baik.

Berdasarkan Penelitian terdahulu, telah dilakukan beberapa penelitian implementasi nilai-nilai pendidikan (Julaiha, 2014; Kurikulum, 2014; Rohinah, 2017; Sukitman \& Ridwan, 2016; Supranoto, 2015; Wathoni, 2013) serta beberapa penelitian dalam tinjauan pendidikan islam (Aslan, 2017; Faturrahman, 2016; Hidayati, 2016; Ibrahim, 1990; Ismail, 2013; Muspiroh, 2016; Najahah, 2016; Qodir, 2014; Ridlwan, 2013; Rifai, 2016; Sukring, 2016; Ulwan, 1992; Zainuddin, 2015) Namun belum ada penelitian yang meneliti implementasi nilai-nilai pendidikan dalam pendidikan Islam. Maka, keterbaruan penelitian ini terletak pada implementasi nilai-nilai pendidikan dalam pendidikan Islam

\section{METODE PENELITIAN}

Jenis penelitian yang digunakan adalah model penelitian kualitatif dengan kajia literatur. Penelitian kualitatif bertujuan memperoleh gambaran seutuhnya mengenai suatu hal menurut pandangan manusia yang diteliti. Penelitian kualitatif berhubungan dengan ide, persepsi, pendapat, atau kepercayaan orang yang diteliti; kesemuanya tidak dapat diukur dengan angka

\section{HASIL KAJIAN DAN PEMBAHASAN}

\section{Konsep Nilai}

Salah satu ruang lingkup dalam kajian filsafat adalah bidang aksiologi. Dalam bidang aksiologi, pemikiran filsafat tersebut diarahkan pada persoalan nilai, baik dalam konteks estetika, moral maupun agama.(Muhmidayeli, 2013) Aksiologi menurut istilah berasal dari dua kata axio dan logos, axios artinya nilai atau sesuatu yang berharga, serta logos artinya akal, teori, axiologi artinya teori dan nilai, penyelidikan mengenai kodrat, kriteria dan status metafisik dari nilai. (Mustansyir \& Munir, 2001) Menurut Kamus besar Bahasa Indonesia aksiologi adalah kegunaan ilmu pengetahuan yang berguna bagi kehidupan manusia, kajian tentang nilai-nilai khususnya etika. 
(Wihadi, 1998) Berdasarkan beberapa para pendapat ahli tentang pengertian aksiologi ini, maka pembahasan dalam bagian ini tentang nilai hakikat yang meliputi: pengertian nilai, jenis-jenis nilai, karakteristik nilai dan aliran dalam hakikat nilai. . (Mustansyir \& Munir, 2001)

\section{a. Pengertian Nilai}

Nilai ialah sesuatu yang berbentuk abstrak, yang bernilai mensifati dan disifatkan terhadap sesuatu hal yang ciri-cirinya dapat dilihat dari prilaku seseorang, yang memiliki hubungan yang berkaitan dengan fakta, tindakan, norma, moral, dan keyakinan. Menurut Muhmidayeli, pengertian nilai adalah "gambaran sesuatu yang indah, yang mempesona, menakjubkan, yang membuat kita bahagia dan senang serta merupakan sesuatu yang menjadikan seseorang ingin memilikinya.(Muhmidayeli, 2013)

Pendapat lainnya mendefinisikan nilai adalah "suatu pola normatif yang menentukan tingkah laku yang diinginkan bagi suatu sistem yang berkaitan dengan lingkungan sekitar dan tidak membedakan fungsi-fungsi tersebut. bagianbagiannya".(Arifin, 2012) Adapun menurut Rohmat Mulyana, nilai adalah "rujukan terhadap keyakinan dalam menentukan suatu pilihan”. (Mulyana, 2011)

Berdasarkan beberapa para pendapat ahli tersebut dipahami bahwa pengertian nilai sangatlah luas dan kompleks. Nilai membantu seseorang untuk mengindentifikasikan apakah perilaku tersebut itu baik atau tidak, boleh atau tidak boleh, benar atau salah, sehingga dapat menjadi pedoman dalam bertingkahlaku dalam kehidupan bermasyarakat dan sebagai makhluk individu maupun makhluk sosial.

\section{b. Jenis-Jenis Nilai}

Dalam aksiologi ada dua komponen yang mendasar yang merupakan jenis-jenis nilai, yaitu nilai etika dan nilai estetika. Sebagaimana yang dikemukakan Amsal Bakhtiar, bahwa "teori tentang nilai yang terdapat dalam filsafat mengarah pada permasalahan etika dan estetika.(Bakhtiar, 2013) Etika yang berkenaan dengan masalah kebaikan, dan estetika berkenaan dengan masalah keindahan. (Kattsoff, 1992)

\section{1) Etika}

Menurut Istilah etika berasal dari bahasa Yunani "ethos" yang berarti adat atau kebiasaan. Sedangkan dalam bahasa latin, istilah moral adalah "mores" kata jamak dari 
mos yang artinya adat kebiasaan. (Bakri, 1970) Dalam istilah lain, para ahli yang berkecimpung dalam bidang etika menyebutkan dengan moral, berasal dari bahasa Yunani, juga berarti kebiasaan.

Etika merupakan suatu teori tentang nilai-nilai adat atau kebiasaan , pembahasan secara teoritis tentang nilai-nilai adat dan kebiasaan ,dan terdapat ilmu kesusilaan yang memuat dasar untuk berbuat susila. Sedangkan moral pelaksanaannya dalam kehidupan.(Sadulloh, 2007) Makna etika juga dapat dipakai dalam dua bentuk arti, yang pertama, etika merupakan suatu kumpulan ilmu pengetahuan yang mengenai penilaian terhadap suatu perbuatan manusia. Arti yang kedua, etika merupakan suatu predikat yang dapat dipakai untuk membedakan perbuatan manusia dalam hal-hal tersebut(Bakhtiar, 2013)

Etika merupakan cabang dari filsafat aksiologi yang membahas masalahmasalah adat dan kebiasaan. Kajian etika lebih terfokus terhadap perilaku, norma, dan adat istiadat yang berlaku pada kelompok tertentu. Etika merupakan cabang filsafat tertua karena sudah menjadi kajian yang menarik sejak masa sokrates dan para kaum sophis. Di situlah dipersoalkan mengenai masalah kebaikan, keutamaan, keadilan dan sebaginya. Jadi, tema pokok yang menjadi perbincangan didalam etika adalah nilai "betul" (right) dan "salah" (wrong) dalam arti moral dan immoral. (Warsito, 2012)

Berdasarkan beberapa pendapat para ahli tersebut dipahami bahwa etika adalah cabang filsafat yang membicarakan perbutan manusia. Cara memandang seseorang dari sudut prilaku baik atau tidak, etika merupakan suatu cabang dari filsafat yang membahas tentang perilaku manusia. Oleh karena itu, diperlukan etika, yang berguna untuk mencari tahu apa yang semestinya dilakukan oleh manusia. Secara metodologis, tidak semua hal dapat menilai perbuatan dan dapat dikatakan sebagai etika. Etika harus memiliki sikap kritis, metodis, dan sistematis dalam melakukan refleksi. Karena sebab itu etika dikatakan suatu cabang ilmu. Sebagai suatu ilmu, etika memiliki objek yakni tingkah laku manusia. Akan tetapi memiliki perbedaan dengan ilmu-ilmu lainnya yang sama-sama meneliti tingkah laku manusia. Sudut pandang etika bersifat normatif. artinya etika melihat dari sudut baik dan buruk terhadap perbuatan manusia.

\section{2) Estetika}

Estetika merupakan salah satu cabang ilmu filsafat. Estetika adalah nilai-nilai yang berhubungan dengan nilai keindahan dengan pengalaman-pengalaman yang berkaitan 
dengan seni. Sebagaimana yang dikemukakan Muhmidayeli bahwa "estetika merupakan studi nilai dalam realitas keindahan”. (Muhmidayeli, 2013) Sedangkan menurut Amsal Bakhtiar, estetika berkaitan dengan nilai tentang pengelaman keindahan dan berkaitan dengan manusia terhadap lingkungan dan fenomena di sekelilingnya.(Bakhtiar, 2013)

Keindahan memiliki arti bahwa segala sesuatu memiliki unsur-unsur yang tertata secara berurutan dan harmonis dalam suatu hubungan yang utuh menyeluruh. Artinya suatu objek yang indah tidak hanya memiliki sifat yang selaras serta memiliki bentuk yang baik, melainkan harus memiliki kepribadian .

\section{c. Karakteristik Nilai}

Ada beberapa beberapa karakteristik nilai yang berkaitan dengan teori nilai, yaitu :

1) Nilai Objektif atau Subjektif

Nilai dikatakan objektif apabila ia tidak bergantung pada subjek atau kesadaran yang menilai; sebaliknya nilai dikatakan subjektif jika eksistensinya, arti, dan validitasnya tergantung pada reaksi subjek yang menilainya, tanpa melihat apakah ini bersifat psikis ataupun fisik. (Sadulloh, 2007) Nilai objektif mengatakakn segala sesuatu yang pasti benar secara objektif, maka tindakan dan kualitasnya adalah baik secara inheren. Sedangkan nilai subjektif, nilai sesuatu bukan dari sesuatu yang dinilai, tetapi karena adanya seseorang yang menilainya. (M, 2005)

Berdasarkan kedua pendapat tersebut dipahami bahwa segala suatu nilai dapat dikatakan objektif apabila nilai-nilai itu tidak bergantung terhadap subjek atau kesadaran yang menilainya. Tolak ukur segala suatu gagasan terdapat pada objeknya, bukan pada subjek yang melakukan penilaian. Kebenaran tidak bergantung terhadap pendapat individu melainkan pada objektivitas fakta. Sebaliknya, nilai menjadi subjektif, jika subjek ikut berperan dalam memberikan penilaian; kesadaran manusia menjadi tolak ukur penilaian. Oleh karena itu nilai subjektif selalu memperhatikan dari berbagai sudut pandang yang dimiliki akal budi manusia, seperti perasaan yang akan mengasah kepada suka atau tidak suka, senang ataupun tidak senang.

2) Nilai Obsolut atau Relatif

Suatu nilai yang dapat dikatakan absolute atau abadi, jika nilai yang berjalan saat ini sudah berjalan sejak masa lampau dan akan terus berlaku sepanjang masa, serta akan 
berlaku terhadap siapapun tanpa melihat ras, serta kelas social. Disisi lain ada yang berpendapat bahwa semua nilai relatif sesuai dengan keinginan atau harapan manusia. (Sadulloh, 2007)

\section{d. Aliran dalam Hakikat Nilai (Aksiologi)}

Aksiologi dalam pandangan aliran filsafat dipengaruhi oleh cara pandang dan pemikiran filsafat yang dianut oleh masing-masing aliran filsafat, yakni:

\section{1) Teori nilai menurut idealisme}

Menurut idealisme memiliki pandangan bahwa hukum-hukum etika merupakan hukum kosmos. Oleh karena itu seseorang dapat dikatakan baik, jika banyak melakukan interaksi didalam pelaksanaan hukum-hukum tersebut. Menurut idealisme, sikap, prilaku, dan ekspresi perasaan juga memiliki keterkaitan dengan kualitas baik dan buruk. Orang yang memakai pakaian formal seperti dalam upacara atau peristiwa lain yang membutuhkan suasana tenang haruslah bersikap formal dan teratur. Oleh sebab itu, ekspresi perasaan yang mencerminkan adanya segala kesungguhan dan kesenangan terhadap pakaian resmi yang dikenakan dapat menampilkan keindahan pakaian dan suasana kesungguhan tersebut.(Jalaluddin \& Idi, 1997) kelompok idealisme yang memiliki pemahaman bahwa sommun bonum (ide kebaikan tertinggi) kehidupan manusia sesungguhnya telah ada bersamaan sejak kemunculan dirinya kedunia yang menjadikan pemahaman, bahwa nilai apapun akan selalu bersifat tetap atau dapat tidak berubah-ubah, absolut. Nilai-nilai kebaikan dan kebajikan yangmemiliki kebenaran dan nilai yang indah sesungguhnya tidak dapat berubah secara fundamental dari suatu masa ke masa berikutnya, dari masyarakat satu ke masyarakat berikutnya. Essensinya tetap bersifat konstan dan tidak akan pernah berubah. Idealisme memiliki keyakinan bahwa nilai yang sebenarnya bukan hanya produk yang berasal dari manusia, akan tetapi merupakan hasil dari produk alam semesta. Oleh sebab itu, maka aliran ini mengakui bahwa apapun yang digolongkan baik atau buruk, benar atau salah, cantik atau jelek, bahagia atau sengsara dan yang seirama dengan ini secara fundamental tidak dapat pernah berubah dari generasi kegenerasi. Dan sebab itu, tugas manusia adalah bagaimana caranya agar nilai-nilai dari kebaikan itu terealisasi didalam keseluruhan aktivitasnya di dunia.

\section{2) Teori nilai menurut realisme}


Teori nilai adalah sumber dari segala ilmu pengetahuan manusia terdapat pada keteraturan lingkungan hidupnya. Realisme memiliki sudut pandang bahwa prilaku baik atau buruk didalam kehidupan manusia bergantung pada keturunan dan lingkungan hidupnya. Perbuatan seseorang merupakan hasil dari perpaduan antara pengaruh fisiologis dan pengaruh lingkungan. George Santayana memadukan sudut pandangan idealisme dan realisme didalam suatu sintesa yang berpendapat bahwa "nilai" itu tidak dapat ditandai dengan suatu konsep tunggal, karena minat, perhatian, serta pengalaman seseorang dapat menentukan kualitas tertentu. Walaupun idealisme menjunjung tinggi asas otoriter atau nilai-nilai tersebut, akan tetapi, tetap mengakui bahwa pribadi secara aktif turut menentukan nilai-nilai tersebut atas dirinya sendiri.(Jalaluddin \& Idi, 1997)

\section{3) Teori nilai menurut aliran pragmatisme}

Menurut aliran Pragmatis, nilai adalah relatif. Etika serta moral tidaklah permanen ataupun tidak konstan, namun akan selalu berubah seperti halnya budaya dan perubahan masyarakat. Hal tersebut bukanlah untuk mengakui bahwa nilai moral harus berubah-ubah dari waktu ke waktu.(Muhmidayeli, 2013) Pendapat lainnya juga menyatakan bahwa nilai-nilai dalam pragmatisme bersifat relatif. (Ramayulis \& Nizar, 2010)

Bagi kelompok pragmatis nilai itu bersifat relative, etika dan aturan-aturan moral tidak permanen tetapi tampil karena perubahan budaya dan masyarakat tersebut. Hal Ini tidak menunjukan bahwa nilai-nilai moral itu bersifat fluktuatif dari masa ke masa. Sehingga dapat dinyatakan bahwa tidak ada perintah tertentu yang di anggap sebagai pengikat secara menyeluruh tanpa memperhatikan lingkungan dimna ia di akui dan di implementasikan. Misalnya, Larangan “jangan membunuh" bukanlah prinsip yang absolut. Suatu saat prilaku membunuh, umpamanya, dapat saja menjadi benar ketika dilakukan untuk mempertahankan diri atau mungkin karena memelihara kehidupan orang lain.

\section{4) Teori Nilai dalam Islam}

Dalam Islam, bahwa setiap nilai yang terdapat dunia ini tentu mengandung nilainilai yang telah diberikan oleh Allah SWT terhadap ciptaan-Nya. yang dapat menentukan apakah sesuatu itu mempunyai nilai atau tidak, tergantung kepada manusianya sebagai mu'abbid, khalifah fil ardh maupun 'immarah fil ardh. Karena 
manusia sebagai subjek diatas dunia ini, maka semua nilai itu haruslah mengacu kepada etika. Jika dapat kita cermati Allah SWT menciptakan manusia di dunia ini agar menjadi hamba-hamba yang selalu mengabdi kepada-Nya, itulah hamba-hamba yang berprilaku baik kepada-Nya, yaitu hamba-hamba yang ber-etika. Menurut Muhmidayeli moralitas adalah tujuan manusia. (Muhmidayeli, 2007)

Dalam Islam, segala sesuatu yang dicipatakan Allah SWT mempunyai nilai yang baik atau mulia, dan bermanfaat bagi umat manusia. Tidak ada satupun ciptaan Allah SWT yang didunia ini tidak ada nilainya atau nilai yang tidak baik, semua itu bergantung kepada manusianya sendiri sebagai 'immarah fil ardh. Sebagaimana yang difirmankan Allah SWT berfirman dalam Q.s Ali Imran ayat 191:

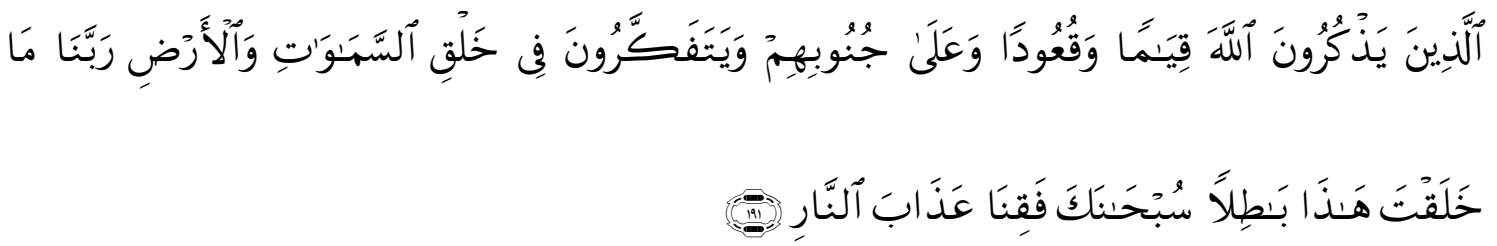

Artinya: "(yaitu) orang-orang yang mengingat Allah sambil berdiri atau duduk atau dalam keadan berbaring dan mereka memikirkan tentang penciptaan langit dan bumi (seraya berkata): "Ya Tuhan Kami, Tiadalah Engkau menciptakan ini dengan sia-sia, Maha suci Engkau, Maka peliharalah Kami dari siksa neraka”

Oleh karena itu sudah seharusnya kita menjadi orang yang baik, bahkan kata Allah SWT berkata bahwa kita harus menjadi orang yang terbaik. Sebagaimana Allah SWT berfirman dalam Q.S Ali Imaran ayat 110, yang artinya: "Kamu (umat Islam) adalah umat sebaik-baik yang dilahirkan untuk manusia,(karena kamu) menyuruh(berbuat) yang ma'ruf, dan mencegah dari yang mungkar dan beriman kepada Allah SWT.

Menurut Muhmidayeli, ayat ini menjelaskan bahwa agar kita menjadi sebaikbaik umat, yaitu amar ma'ruf( berbuat yang baik), dan nahi munkar ( mencegah yang buruk ), dan beriman kepada Allah SWT. Dan penjelasan tersebut mengandung nilainilai yang menyuruh perbuatan baik, mencegah yang mungkar dan beriman kepada allah dan dapat dikerjakan oleh umat manusia di dunia ini. ayat tersebut mengandung dua makna sebagai yaitu Iman dan amal soleh. Iman yang berarti keyakinan kita kepada Allah swt, serta amar ma'ruf( menyuruh berbuat baik) dan nahi mungkar(mencegah perbuatan buruk ) itulah yang disebut sebagai amal soleh. Apabila dalam diri seorang 
hamba tersebut telah teraplikasi dari penjelasan itu, maka dapat disebut oleh muhmidayeli sebagai manusia yang bertauhid. (Muhmidayeli, 2013)

Manusia yang bertauhid dapat dikatakan sebagai Insan kamil (manusia sempurna), atau manusia paripurna. Semakin tinggi nilai iman dan amal soleh seseorang, maka semakin mulia dia disisi Allah SWT. Jadi makna yang terkandung dalam ayat tersebut, diantaranya manusia harus senantiasa melakukan perbuatan hal-hal yang terbaik dalam hidupnya. Disisi Allah SWT setiap mengerjakan kebaikan itu akan dinilai sebagai amal soleh, walaupun perbuatan baik yang dilakukan manusia itu ibaratnya mengerjakan kebaikan seberat zarrah ia akan mendapat balasannya didunia ini, dapat dibaca dalam Firman AllahQ.S Az-Zalzalah ayat 7.

Hakikat nilai dalam Islam itu merupakan suatu yang dapat mendatangkan manfaat bagi kehidupan manusia, alam, serta mendapatkan keridhaan dari Allah SWT, yang dapat dijabarkan dengan luas dalam konteks Islam. Penempatan posisi nilai yang tertinggi ini adalah dari Tuhan, juga dianut oleh kaum filosis idealis tentang adanya hirarki nilai. Menurut pendapat kaum idealis, nilai spiritual itu lebih tinggi dari nilai material. Kaum idealis merupakan nilai agama yang pada posisi tertinggi, karena menurut mereka nilai-nilai ini akan membantu kita untuk merealisasikan tujuan yang tertinggi, menyatukan susunan nilai spiritual. (Muhmidayeli, 2013) dalam hal ini Islam, mengakui bahwa landasan utama dari kebaikan nilai adalah dari Allah SWT, yang kemudian akan diutus oleh Nabi dan Rasul untuk lebih memperjelas pesan-pesan tuhan kepada umat manusia. Jadi Nilai-nilai didalam Islam ialah Al-Qur'an dan Hadits atau Sunnah Rasulullah SAW. Dalam menjabarkan kedua dimensi ini, diperlukan adanya daya akal atau rasional manusia agar pesan-pesan tersebut dapat disampaikan kepada tataran hidup sepanjang zaman. Akal memperbolehkan, bahkan raga dan rohani dalam memahami sesuatu hal ini dapat dicermati dari firman Allah SWT dalam Surah an-Nahl ayat 78 .

Secara filosofis, yang berkaitan dengan nilai masalah etika. Etika merupakan suatu cabang ilmu filasafat. yang mengkaji nilai-nilai adat dan kebiasaan sebagai tolak ukur tindakan dalam perilaku manusia dalam berbagai aspek kehidupannya. Sumbersumber etika dan moral merupakan hasil dari pemikiran, adat istiadat atau tradisi, ideology bahkan dari agama. Dalam konteks etika pendidikan dalam Islam, sumber etika dan nilai-nilai yang paling shahih adalah Al-Qur'an dan Sunnah Nabi SAW yang 
kemudian dikembangkan oleh hasil ijtihad para ulama. Nilai-nilai yang bersumber kepada adat-istiadat atau tradisi dan ideology sangat rentan dan situasional. Sedangkan nilai-nilai Qur'ani, yaitu nilai yang bersumber dari Al-Qur'an dan kuat, karena merupakan ajaran Al-Qur'an yang bersifat mutlak dan universal.(Al Munawar, 2005)

Agar nilai-nilai tersebut berguna maka nilai-nilai itu harus diimplementasikan dalam kehidupan sehari-hari. kepada seorang manusia yang mengamalkan nilai-nilai keIslaman yang berasal dari nilai-nilai ilahiyah dalam hidupnya, akan sampai kepada Insan Kamil(manusia sempurna), atau manusia tauhid. Insan kamil merupakan manusia yang sempurna yaitu orang-orang yang beriman dan bermoral (etika), yang mencakup didalam kekuasaan ilmu yang dimilikinya,Allah SWT bertujuan untuk menciptakan manusia.

\section{Konsep Pendidikan Nilai dalam Islam}

Konsep Pendidikan adalah nilai didalam Islam yang mempunyai dua istilah yang dapat digunakan yaitu nilai menurut bahasa Arab, yaitu "fadilah" atau"qimah", yang dapat dipakai dan berkaitan dengan nilai-nilai moral yaitu: "fadilah" sedangkan "qimah" yaitu lebih dipakai untuk menyatakan nilai dalam konteks ekonomi dan hal-hal yang berhubungan dengan benda materi. (Muhmidayeli, 2013)

Mengatakan nilai dalam pendidikan agama Islam, berarti berbicara tentang hakikat nilai pendidikan agama Islam, yang memiliki proses, dan bertujuan kepada Pendidikan agama Islam itu tersebut . Hakikat Pendidikan agama Islam mempunyai arti yang sama dengan tujuan pendidikan Islam. Achmadi menjelaskan bahwa Pendidikan agama Islam adalah segala usaha untuk memelihara fitrah manusia, serta sumber daya insani yang pada umum nya bertujuan untuk membentuk manusia yang sempurna (Insan kamil) sesuai dengan norma Islam. Begitu dengan tujuan hakikat Pendidikan agama Islam yang dikatakan oleh Zakiah Daradjat adalah untuk membentuk kepribadian seseorang menjadi Insan Kamil dengan bentuk taqwa. Dalam proses pendidikan agama Islam, seharusnya berlandaskan nilai-nilai ajaran Islam, yaitu yang berlandaskan AlQur'an dan Hadits.

Pendidikan merupakan suatu kegiatan yang mulia didalam Islam dan mengandung nilai-nilai kebaikan dan kebajikan bagi manusia, oleh karena itu aktifitas manusia dapat menjadikan manusia sebagai makhluk yang mempunyai nilai moral, baik dalam fungsinya sebagai mu'abbid, khalifah fil ardh atau 'immarah fil ardh. Dalam 
pokok bahsan pendidikan agama Islam, nilai-nilai moral keagamaan menjadi salah satu bagian yang integral dalam setiap gerak usaha kependidikan yang tersusun secara struktural-formal tidak hanya tercantum dalam tujuan institusional pendidikan saja, tetapi seharusnya juga terjalin erat dalam setiap denyut nadi aktifitasnya. (Muhmidayeli, 2013)

Moral/akhlak merupakan nilai-nilai dan norma-norma yang menjadi pegangan sekelompok orang dalam mengatur tingkah lakunya. Moral berkenaan dengan suatu kegiatan manusia yang memandang suatu prilaku manusia dalam prilaku baik atau buruk, benar atau salah, tepat atau tidak tepat, atau menyangkut cara seseorang dalam bertingkah laku dalam hubungan dengan orang lain.

Nilai dalam kontek Islam terbagi kepada dua macam, yaitu yang tetap dan yang tidak tetap. Yang pertama yaitu yang bersifat tetap dapat disebut dengan nilai-nilai wajib yang entitasnya telah disepakati oleh seseorang dan jelas, dapat disebut nilai mutlaq. Sedangkan yang kedua bersifat fleksibel merupakan lahir dari dinamika masyarakat, disebut juga sebagai nilai muqayyad.

Pada hakikatnya, nilai akan tidak timbul dengan sendirinya, karena ia merujuk pada sikap menerima atau menolak seseorang atau sekelompok orang terhadap suatu realitas dalam hubungan subjek atau objek yang prosesnya tidak dapat dilepaskan dari ilmu pengetahuan dan wawasan subjek penentu nilai. Oleh karena itu, nilai ini akan berkembang dan dapat berubah-ubah seiring dengan kecendrungan dan sikap mental individu-individu dalam suatu masyarakat. Hal ini berkaitan erat dengan upaya pendidikan sebagai wadah perubahan dan perbaikan perilaku seseorang yang dapat menentukan sikap prilaku hidup seseorang dalam bermasyarakat. Pada dasarnya nilai ini tidak berada di dalam dunia pengalaman, akan tetapi ia berada dalam pikiran.

Secara singkat nilai yaitu menjadikan standar perilaku seseorang untuk hidup sesuai dengan nilai-nilai yang telah diyakininya. Sebagai standar perilaku, nilai moral dapat membantu subjek dan menentukan pengertian sederhana terhadap suatu jenis perilaku. Dalam pengertian yang lebih luas nilai akan membantu subjek moral untuk mengidentifikasi apakah sesuatu perilaku itu perlu atau tidak, baik atau buruk serta mendorongnya untuk membuat analisis dari suatu perilaku moral tertentu yang menuju pada kesimpulan-kesimpulan yang merupakan landasan atau kecendrungan yang akan menjadi sikap yang akan menetukan corak suatu kepribadian. 
Paling tidak ada tiga unsur yang tidak dapat terlepas dari nilai, yaitu:

a) Nilai yang berkaitan dengan subjek, karena memang suatu nilai lahir dari bagaimana subjek menilai realitas, namun bukan berarti makna keputusan pada subjek nilai dapat mentidak adakan hal-hal diluar dalam dirinya. Nilai berkaitan dengan keyakinan seseorang atas sesuatu yang dapat mewajibkan dirinya untuk melestarikan nilai tersebut.

b) Bahwa nilai dapat diaplikasikan dalam suatu tindakan secara praktis, artinya nilai sangat berkaitan erat dengan aktifitas seseorang. beramal adalah bukti nyata bahwa seseorang memiliki nila

c) Bahwa nilai-nilai tersebut bersifat subjektif karena nilai-nilai tersebut berhubungan denga sifat-sifat yang dapat ditambah oleh subjek pada sifat-sifat yang dimiliki objek. Oleh karena itu adalah lazim jika objek yang sama mempunyai nilai yang berbeda di kalangan masyarakat.(Muhmidayeli, 2013)

Melihat bahwa kesadaran nilai adalah kunci dari perwujudan nilai-nilai itu, maka dalam pembelajaran pendidikan agama Islam, harus menanamkan nilai -nilai yang semesinya dapat menumbuhkan kesadaran kepada subjek didik bahwa suatu nilai dapat berguna bagi kenyataan dalam kehidupannya, terutama dalam kaitannya dirinya dengan alam semesta dan Tuhan. Ini berarti bahwa pendidikan erat kaitannya dengan nilai-nila tersebut. Sehingga nilai-nilai kemanusiaan itu benar-benar dapat diwujudkan dalam alam realitas manusia. Menurut pandangan Muhmidayeli, bahwa tujuan pendidikan agama Islam sama dengan tujuan diciptakannya manusia di dunia ini oleh Allah SWT.

Sehingga kondisi pendidikan agama Islam Pendidikan itu tidak lain adalah upaya untuk menyadarkan dan melakukan untuk menjadi manusia sebagai manusia utuh atau dengan kata lain, pemanusiaan mempunyai tugas utama dalam pendidikan agama Islam. (Muhmidayeli, 2007)

Pendeknya Pendidikan agama Islam itu merupakan sarat salah satunya dalam nilai-nilai keIslaman. KeIslaman yang dimaksud keIslaman yaitu Islam yang menyeluruh, atau kaffah, yang menjadikan manusia sebagi manusia sempurna(Insan Kamil), merupakan tujuan penciptaan manusia. dalam Pendidikan agama Islam sangat mengutamakan, dan menjunjung tinggi nilai-nilai keIslaman itu guna untuk mencapai 
tujuan pendidikan tersebut.

\section{Implikasi Pendidikan Nilai dalam Pendidikan Agama Islam}

Implikasi Pendidikan dalam nilai Pendidikan Agama Islam Berdasarkan konsep pendidikan nilai agama Islam tersebut, maka implikasinya yaitu pendidikan agama Islam adalah sebagai berikut:

\section{a. Tujuan pendidikan agama Islam}

Tujuan pendidikan agama Islam haruslah sesuai dengan nilai-nilai ajaran pendidikan agama Islam, yaitu untuk menjadikan manusia memenuhi tugas kekhalifahaannya sebagaimana tujuan diciptakannya manusia. Sebagaimana yang dikemukakan Munzir Hitami menyatakan bahwa tujuan pendidikan agam Islam haruslah mencakup tiga hal yaitu: 1) pertama tujuan bersifat teleologik, yakni kembali kepada Tuhan, 2) kedua tujuan bersifat aspiratif, yaitu kebahagiaan dunia sampai akhirat, dan 3) dan yang ketiga tujuan bersifat direktif yaitu menjadi makhluk pengabdi kepada Tuhan. (Hitami, 2004)

Oleh sebab itu apapun mata pelajarannya, maka dalam merumuskan tujuan pendidikan agama Islam haruslah mencakup ketiga hal tersebut yaitu agar peserta didik menjadi manusia yang mampu menggunakan ilmu pengetahuan dan keterampilan untuk selalu kembali kepada Tuhan, dan menjadi manusia yang mampu memanfaatkan ilmu pengetahuan dan keterampilannya untuk mencapai kebahagiaan di dunia maupun di akhirat, dan dengan keluasan ilmu pengetahuannya tersebut dapat menjadikannya sebagai manusia yang taat dan shalih, sehingga apabila kesemuanya dimiliki peserta didik, titik akhirnya adalah mewujudkan peserta didik menjadi insan kamil.

\section{b. Materi pendidikan agama Islam}

Materi tentang pendidikan agama Islam haruslah mengandung nilai-nilai dan ajaran-ajaran pendidikan agama Islam. Untuk itu, ketika menyusun materi dalam mata pelajaran pendidikan agama Islam hendaknya memasukkan nilai-nilai keIslaman di dalamnya, terutama dalam materi pendidikan umum, sehingga ketika peserta didik tersebut menjadi seorang ilmuan dia menjadi ilmuwan yang juga memahami ajaran agamanya dan mengaplikasikan pengetahuannya sesuai dengan nilai-nilai dan ajaran agamanya.

Penyusunan materi tentang pendidikan agama Islam harus mencakup materi pendidikan ketauhidan, fikih, ibadah, dan lain sebagainya, yang mengantarkan peserta 
didik menjadi manusia yang insan kamil beragama yang memahami ajaran agamanya dengan baik dan mampu mengaplikasikannya dalam kehidupan sehari-hari dengan terampil dan benar. Penyusunan materi pendidikan umum dalam pendidikan agama Islam hendaknya dimasukkan nilai-nilai ajaran Islam, misalnya ketika menyusun materi sains, memasukkan ajaran-ajaran Islam dalam materi tersebut, sehingga peserta didik selalu berada dalam ruang lingkup agamanya dimana pun ia berada.

Hal ini akan berimplikasi pada perilakunya dikemudian hari dalam mengamalkan ilmu pengetahuan dan keterampilannya tersebut sesuai dengan nilai-nilai dan ajaran pendidikan agama Islam.

\section{c. Metode pendidikan agama Islam}

Metode pendidikan agama Islam hendaknya sesuai dengan nilai-nilai dan ajaran pendidikan agama Islam yang bersumberkan kepada Al-Quran dan hadis Rasulullah SAW. Metode keteladanan adalah kunci utama dalam pendidikan agama Islam, karena suatu nilai yang baik dan tidak dapat dipahami siswa apabila siswa hanya mendengarkan dan melihatnya saja. Siswa juga memerlukan contoh keteladanan yang baik, sehingga secara tidak langsung siswa akan terbiasa hidup sesuai dengan ajaran pendidikan Islam sebagaimana dicontohkan oleh para pendidiknya baik orang tua maupun gurunya.

Metode yang mengembangkan akal pikiran kepada peserta didik perlu dilakukan, karena Islam mengakui bahwapeserta didik memiliki potensi akal yang harus dikembangkan. Oleh karena itu dalam menggunakan metode yang mampu mengoptimalkan perkembangan akal siswa perlu digunakan, seperti metode tanya jawab, diskusi, pemecahan masalah, penelitian, eksperimen, dan lain-lain. Metode yang mengembangkan keterampilan siswa baik keterampilan motorik, keterampilan berbicara atau berbahasa, keterampilan berfikir, dan lainnya juga perlu dilakukan, karena Islam mengakui bahwa siswa adalah manusia yang memiliki kelengkapi jasmaniah dan panca indera perlu diberikan pelatihan yang terus menerus sehingga mampu memanfaatkannya dengan baik.

Oleh karena itu metode drill, pembiasaan, demonstrasi, riset, eksperimen, pemberian tugas, juga dapat memberikan efek yang berguna bagi perkembangan motorik dan panca indera siswa.

\section{d. Evaluasi pendidikan agama Islam}


Pendidikan agama Islam Dalam melaksanakan evaluasi, Al-Quran juga memberikan beberapa petunjuk sebagai berikut :(Muhaimin, 2001)

1) Prinsip Kesinambungan (kontinuitas), ajaran pendidikan agama Islam, sangat memperhatikan prinsip dalam kelangsungannya dan berpegang kepada prinsip tersebut untuk mengambil keputusan dari seseorang yang akan menjadi valid atau stabil (Q.S. $46: 13-14)$.

2) Prinsip Menyeluruh (universal), Prinsip yang melihat seluruh aspek, terdiri dari kepribadian, ketajaman hafalan, pemahaman ketulusan, kerajinan, sikap kerjasama, tanggung jawab (Q.S. 99 : 7-8).

3) Prinsip Objektivitas, Dalam mengevaluasi berdasarkan kenyataan yang sebenarnya, tidak boleh dipengaharui oleh hal-hal yang bersifat emosional dan irasional (Q.S 5: 8). (Tabrani Rusyam, dkk, 1989 : 211)

Islam memandang bahwa nilai-nilai dalam ajaran pendidikan agama Islam tersebut harus bersifat universal baik itu jasmani maupun rohani, duniawi dan ukharwi, materi maupun non materi, alam jasadi dan gaib. Oleh sebab itu dalam melaksanakan evaluasi pendidikan agama Islam haruslah juga bersifat universal. Jangan hanya mengevaluasi dimensi jasmani yang dapat dilihat oleh manusia secara kongkrit tetapi juga dimensi rohani secara abstrak dengan pola-pola evaluasi yang bervariasi sesuai objek yang dievaluasi. Islam juga mengakui bahwa manusia memiliki potensi akal, ruh, nafs, dan kalbu, oleh sebab itu, didalam mengevaluasi pendidikan Islam haruslah memenuhi kesemua dimensi potensi manusia tersebut, harus sesuai dengan karakteristik manusia yang memiliki perbedaan dan tumbuh berkembang sesuai dengan tahapannya.

Evaluasi pendidikan agama Islam tidak hanya dapat bertujuan untuk mengetahui perkembangan pada aspek kognitif (akal) tetapi juga bertujuan untuk mengetahui perkembangan akhlak dan motorik siswa.

\section{e. Peran pendidik dalam pendidikan agama Islam}

Peran pendidik dalam pendidikan agama Islam mempunyai nilai-nilai dan ajaran dalam pendidikan agama Islam banyak sekali mengatur tentang peran pendidik. Pendidik sebagai pelaksana pendidikan, maka hendaklah memiliki nilai-nilai keIslaman di dalam dirinya. An-Nahlawi, mengutip oleh Ramayulis, menjelaskan bahwa seorang pendidik dalam Islam mempunyai tugas pokok yaitu: (Ramayulis \& Nizar, 2010) 
1) Tugas Pensucian, yakni mengembangkan dan membersihkan jiwa peserta didik agar dapat mendekatkan diri kepada Allah SWT, dan menjauhkan diri dari keburukan, dan menjaganya agar tetap berada pada fitrahnya(kesucian).

2) Tugas seorang pendidik, yakni menyampaikan berbagai ilmu pengetahuan dan pengalaman kepada peserta didik untuk diterjemahkan dalam tingkah laku dan kehidupannya.

Guru haruslah memiliki keimanan dan ketakwaan, memiliki akhlak yang baik, selain menguasai berbagai ilmu pengetahuan dan keterampilan yang berkaitan dengan tugas profesinya. Guru yang beriman,dan bertakwa, berakhlak mulia, patut menjadi contoh yang baik bagi siswanya. Karena tugas guru itu bukan hanya mentransfer berbagai ilmu pengetahuan dan keterampilan kepada siswa, akan tetapi juga perlu memberikan pendidikan akhlak kepada siswanya, dan guru yang memiliki keimanan, ketakwaan dan memiliki akhlak mulia yang akan mampu melaksanakan tugas tersebut dengan baik dan optimal, sebagai suri teladan yang baik bagi para siswanya.

\section{SIMPULAN DAN SARAN}

Berdasarkan pembahasan pada bab sebelumnya diperoleh beberapa kesimpulan sebagai berikut:

1. Konsep pendidikan nilai dalam Islam adalah:

a. Nilai yang baik tidak langsung muncul dengan sendirinya akan tetapi melalui proses pendidikan sesuai dengan norma-norma ajaran Islam.

b. Dengan kata lain nilai menjadi tolak ukur perilaku yang menjadikan orang berusaha untuk hidup sesuai dengan nilai-nilai yang telah diyakininya.

c. Nilai terimplementasi didalam tindakan praktis, artinya nilai sangat berhubungan dengan kegiatan seseorang. Penanaman nilai dengan menumbuhkan kesadaran terhadap siswa bahwa suatu nilai berguna bagi realitas kehidupannya.

d. Pendidikan Islam sangat mementingkan, dan menjunjung tinggi nilai-nilai keIslaman untuk mencapai tujuan pendidikan tersebut.

2. Implikasi pendidikan nilai dalam pendidikan agama Islam adalah:

a. Tujuan pendidikan agama Islam haruslah selaras dengan nilai-nilai ajaran Islam, yaitu untuk menjadikan manusia memenuhi tugas kekhalifahaannya sebagaimana tujuan diciptakannya manusia. 
b. Bahan pokok materi pendidikan Islam haruslah mengandung nilai-nilai dalam ajaran Islam. Untuk itu, ketika menyusun materi dalam kurikulum pendidikan Islam hendaknya memasukkan nilai-nilai keIslaman di dalamnya.

c. Metode pengajaran pendidikan agama Islam hendaknya selaras dengan nilai-nilai ajaran Islam yang bersumberkan kepada Al-Quran dan hadis Rasulullah SAW yang mengakui potensi manusia dan upaya pengembangannya dengan memanfaatkan potensi manusia tersebut.

d. Evaluasi pendidikan agama Islam haruslah bersifat kontinuitas, komprehensif, dan objektif.

e. Pendidik sebagai pelaksana pendidikan, maka hendaklah memiliki nilai-nilai keIslaman di dalam dirinya, yaitu beriman, bertakwa, dan berakhlak mulia, sehingga mampu menjadi contoh yang baik bagi siswanya. 


\section{DAFTAR PUSTAKA}

Al Munawar, S. A. H. (2005). Aktualisasi Nilai-Nilai Qur'ani Dalam Sistem Pendidikan Islam (II). Ciputat: Ciputat Press.

Arifin, M. (2012). Filsafat Pendidikan Islam. Jakarta: Bumi Aksara.

Aslan. (2017). Pendidikan Remaja Dalam Keluarga di Desa Merabuan, Kalimantan Barat ( Perspektif pendidikan Islam). Al-Banjari, 16(1), 122-135.

Bakhtiar, A. (2013). Filsafat Ilmu. Jakarta: Rajawali Press.

Bakri, H. (1970). Sistemik filsafat. Jakarta: Widjaja.

Faturrahman, M. (2016). Pendidikan Karakter Dalam Perspektif Pendidikan Islam. Edukasi, 4(1), 1-25.

Hidayati. (2016). Pendidikan Anti Korupsi Tinjauan Perspektif Pendidikan Islam. Hikmah: Jurnal Pendidikan Islam, 5(1), 100-128.

Hitami, M. (2004). Mengonsep Kembali Pendidikan Islam. Riau: Infinite Press.

Ibrahim, M. (1990). Pendidikan Agama Islam Untuk Mahasiswa. Yogyakarta: Erlangga.

Ismail, S. (2013). Tinjauan Filosofis Pengembangan Fitrah Manusia dalam Pendidikan Islam. At-Ta'dib, 8(2), 242-263.

Jalaluddin. (1997). Psikologi Agama. Jakarta: Raja Grafindo Persada.

Jalaluddin, \& Idi, A. (1997). Filsafat Pendidikan. Jakarta: Baya Madya Pratama.

Julaiha, S. (2014). Implementasi Pendidikan Karakter Dalam Pembelajaran. Dinamika Ilmu, 14(2), 226-239.

Kattsoff, L. O. (1992). Pengantar Filsafat (V). Yogyakarta: Tiara Wacana.

Kurikulum. (2014). Implementasi Pendidikan Karakter Dalam Kurikulum 2013. Dinamika Ilmu, 14(1), 47-64.

M, A. (2005). Etika dan Pendidikan. Yogyakarta: LSFK2P dan Aditiya Media Pekanbaru.

Mahyuddin. (1999). Kuliah Akhlaq Tasawuf. Jakarta: Kalam Mulia.

Muhaimin. (2001). Paradigma Pendidkan Islam. Bandung: Rosda Karya.

Muhmidayeli. (2007). Membangun Paradigma Pendidikan Islam. Pekanbaru: PPs UIN Suska Riau. 
Muhmidayeli. (2013). Filsafat Pendidikan. Bandung: Refika Aditama.

Mulyana, R. (2011). Mengartikulasikan Pendidikan Nilai. Bandung: Alfabeta.

Muspiroh, N. (2016). Integrasi Nilai Islam Dalam Pembelajaran IPA ( Perspektif Pendidikan Islam). Jurnal Pendidikan Islam, 28(3), 484-498.

Mustansyir, R., \& Munir, M. (2001). Filsafat Ilmu. Yogyakarta: Pustaka Media.

Najahah. (2016). Pemberdayaan Masyarakat Dalam Perspektif Pendidikan Islam. Jurnal Lentera Pendidikan LPPM UM Metro, 14(2), 135-147.

Qodir, Z. (2014). Deradikalisasi Islam dalam Perspektif Pendidikan Agama. Jurnal Pendidikan Islam, 2(1), 85-107.

Ramayulis, \& Nizar, S. (2010). Filsafat Pendidikan Islam. Jakarta: Kalam Mulia.

Ridlwan, N. A. (2013). Konsep Pendidikan Karakter Dalam Perspektif Islam. Komunika, 7(1), 1-11.

Rifai, M. (2016). Peranan Orang Tua Sebagai Wali, Pembimbing, dan Pendidik Pada Perkembangan Anak Dalam Perspektif Pendidikan Agama Islam. Premiere Educandum, 1(1), 1-10.

Rohinah. (2017). Implementasi Nilai-Nilai Islam Dalam Pengembangan Pendidikan Berwawasan Lingkungan Hidup Bagi Anak Usia Dini Di RA UIN Sunan Kalijaga Dan TK Khalifah. Jurnal Pendidikan Anak, 3(1), 1-14.

Sadulloh, U. (2007). Pengantar Filsafat Pendidikan. Bandung: Alfabeta.

Sukitman, T., \& Ridwan, M. (2016). Implementasi Pendidikan Nilai (Living Values Education) Dalam Pembelajaran IPS (Studi Terhadap Pembentukan Karakter Anak Di Tingkat Sekolah Dasar). Profesi Pendidikan Dasar, 3(1), 30-41.

Sukring. (2016). Pendidik dalam Pengembangan Kecerdasan Peserta didik ( Analisis Perspektif Pendidikan Islam). Tadris, 1(1), 57-68.

Supranoto, H. (2015). Implementasi Pendidikan Karakter Bangsa Dalam Pembelajaran Sma. Jurnal Promosi : Jurnal Pendidikan Ekonomi Metro, 3(1), 36-49.

Ulwan. (1992). Pendidikan Anak Menurut Islam Kaidah-kaidah Dasar. Bandung: Remaja Rosdakarya.

Warsito, L. choiril. (2012). Pengantar Filsafat. Surabaya: IAIN Sunan Ampel Press.

Wathoni, K. (2013). Implementasi Pendidikan Inklusi Dalam Pendidikan Islam Kharisul. Ta'allum, 1(1), 99-109.

Wihadi, A. (1998). Kamus Bahasa Indonesia. Jakarta: Balai Pustaka. 
Zainuddin, M. R. (2015). Peran Pondok Pesantren Dalam Perspektif Pendidikan Islam. Edukasi, 3(1), 751-764. 